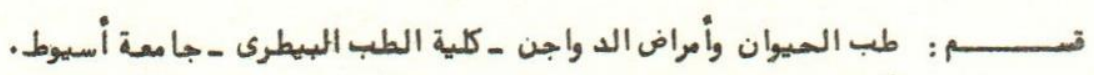

$$
\begin{aligned}
& \text { رئبس القسم: : أ .د / ابراهيم معمد حسن سكر. }
\end{aligned}
$$

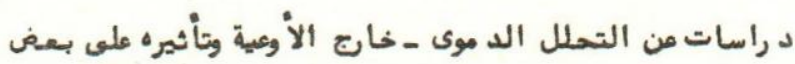

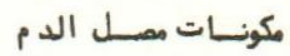

$$
\begin{aligned}
& \text { علـــــى السباعق ، أحمـد عامســر }
\end{aligned}
$$

اجرى البحث على عدد أربعون عينة من مصل الدم فى العاعز المصرى ولقد عينت نسبة الهيموجيلويين

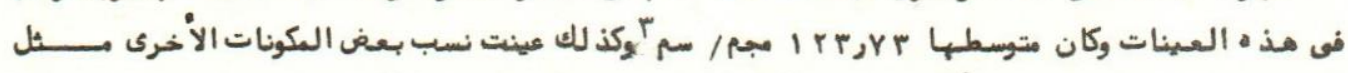

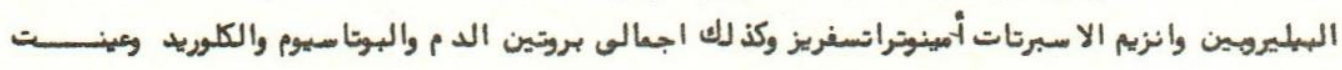

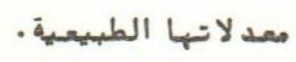

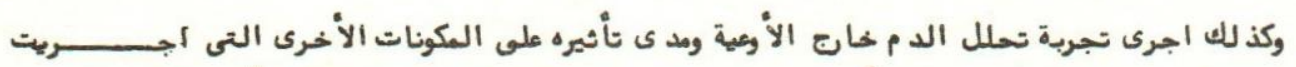

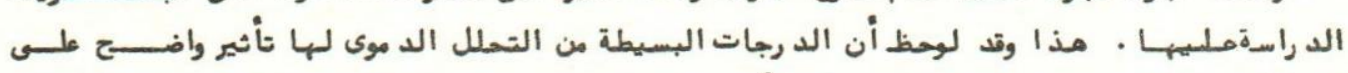

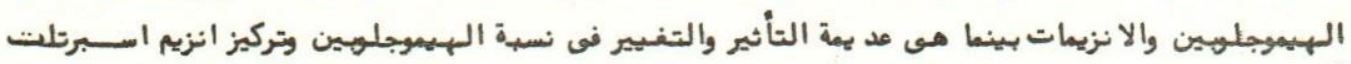

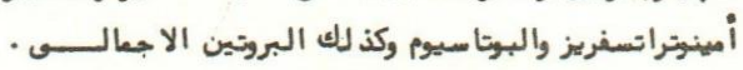




\title{
EFFECTS OF IN - VITRO HAEMOLYSIS SOME CONSTITUENTS OF GOATS SERUM \\ (With 3 Tables)
}

\author{
By
}

\author{
A.H. EL-SEBAIE and A.A. AMER \\ (Received at $14 / 12 / 1982$ )
}

\begin{abstract}
SUMMARY
Serum hemoglobin as well as some other serum parameters, were determined in 40 healthy Egyptian Goats. Mean values of serum hemoglobin was $120.78+5.95 \mathrm{mg} / 100 \mathrm{ml}$; also the values of serum - aspartat amino transferase; serum total bilirubin; serum total protein; serum potassium asnd serum chloride were estimated. In vitro hemolysis was made; the effect of in-vitro hemolysis was studied. A significant adultrations of values of serum hemoglobin; serum spartat amino transferase; serum potassium were marked with silght and severe degree of hemolysis, while other parameters were less or not affected.
\end{abstract}

\section{INTRODUCTION}

In the use and interpretation of laboratory data for the dignosis and mangment of the disease, many factors come in consideration. When errors arise one think immediately of the analysis itself or the computation of the results just as important in this respect however are errors which arise from improper collection and preservation of specimens for analysis. In order to be assured of over - all accuracay of results - some degree of quality control must necessarly practiced in clinical chemistry. This required adequate personal and equipiment accurate standard, clean glassware and so on. As more instrumental analysis is used awarness of limitation and potential sources of errors in such equipment imperative.

Serum is preferable to whole blood or plasma for biochemical analysis because of better preservation of constituents, better correlation with interstitial fluid levels, less chance of alteration due to hemolysis and avoidance of possible errors from added anticoagulent, (MARTINEK, 1966 and CARAWAY, 1962). Normal serum appears visibly hemolytic when the concentration of hemoglobin exceeds $0.02 \mathrm{gm} \%$. Much higher levels could remain undetected in jaundce serum (BEHRENDT, 1957). EL-SEBAIE (1981) reported that the bovine serum showing hemolysis when the serum hemoglobin level exceed $162 \mathrm{mg} / 100 \mathrm{ml}$, while hemoglobin value in bovine serum was $116.48 \mathrm{mg} / 100 \mathrm{ml}$.

Hemolysed specimens do arrive at laboratory quite regulary and the convenience difficulty or even impossibility of obtaninig more a clear specimens from the patients makes it nešsary to decide whether the assay will be refused or performed. In hemolysed serum the cellular contribution to the analysis will be governed by the intercellular concentration of the substances be analysed. The problem of hemolysis is most important if the concentration of measured constituents is much greater in the red cells than in the plasma. Depending upon the ratio of these concentration slight hemolysis can produce significant errors. Concentration of serum potassium, serum aspartat amino transferase, serum lactic dehydrogenase and serum bilirubin were significantly elevated with moderate degree of hemolysis (MCGANN and CARTER, 1960; LAESSIG et al, 1976; DORNER, et al, 1981 and EL-SEBAIE, 1981).

Studies on hemoglobin concentration in goats serum are very scanty in literarature, also the adultration effects of hemolysis on serum constituents were not sufficiently studied. The purpose of this investigation is to determine the values of serum hemoglobin in healthy goats as well as the estimation of some parameters, in addition to the determination of the extent of alteration of values of such parameters under the influence various degree of hemolysis. 


\section{MATERIAL and METHODS}

1- Blood samples were collected from 40 native Egyptian goats. Samples were collected from the jugular vein, and serum was seperated by ordinary methods of hematology. Collection of blood samples and serum-seperation were carried out verycarfully to avoid hemolysis.

2:- Preparation of hemolysate:

Anti-coagulated blood sample (EDTA), was used in this purpose. Blood was centifugated at 3000 r.p.m. - plasma was seperated. Red blood cells were washed three times by the use of normal saline (0.9\%). Washing and centrifugation were repeated several times, and the plasma poured-out. Washed red cells were exposured to repeat freezing and thawing to ensure complete destruction of the red blood cells. Destructed red blood cells were centrifugated, and clear supernatant poured off and used as hemolysate. According to the visual appearnce of the serum, serial dilutions from the hemolysate were made by the use of clear non-hemolysed serum of goats.

The samples were classified according to the density of colour as follows:

1- Non hemolysed serum (-)

2- Slight hemolysed serum $(+)$

3- Severe hemolysed serum (+++)

Biochemical methods:

The following parameters were determined in each samples:

1- Serum hemoglobin was determined by the method modified after RICHTERICH, (1978).

2- Serum potassium was determind flamephotometry by Corning - flamephotometer.

3- Serum chloride was determind by Corning - chloride meter.

4- Serum aspartat amino transferase (AST), serum total bilirubin, serum total protein were estimated bythe use of Boehringer reagent - kits (W. Germany).

\section{RESULTS}

The obtained results in this experiments were presented in tables $(1,2,3)$. The mean values of serum hemoglobin in healthy goats was $120.73 \pm 5.95 \mathrm{mg} / 100 \mathrm{ml}$. The mean values of other measured serum were, serum aspartat amino transferase $(23.6 \pm 3.16 \mathrm{U} / \mathrm{L})$; serum total bilirubin $(11.35 \pm 2.80 \mu \mathrm{mol} / \mathrm{L})$ serum total protein $(99.08 \pm 1.11 \mathrm{~g} / \mathrm{L})$, serum chloride $(109.6 \pm 2.45 \mathrm{mmol} / \mathrm{L})$ and serum potassium $(5.26 \pm 0.93 \mathrm{mmol} / \mathrm{L})$.

The effect of in-vitro hemolysis on the values of the measured parameters were shown in tables $(2,3)$. The mean values of serum hemoglobin, aspartat amino transferase, serum total bilirubin, serum total protein, serum chloride and serum potassium under the influence of severe hemolysis were $462.06 \mathrm{mg} / 100 \mathrm{ml}, 47.80 \mathrm{U} / \mathrm{L} ; 15.83 \mathrm{~mol} / \mathrm{L}$, $99.12 \mathrm{~g} / \mathrm{L}, 101.21 \mathrm{mmol} / \mathrm{L} \quad$ and $10.30 \mathrm{mmol} / \mathrm{L}$ respectively. The result of slight degree of hemolysis were presented in table (2).

\section{DISCUSSION}

The data given here seem to indicate that the normal value of serum hemoglobin in healthy goats was $120.73 \pm 5.45$ $\mathrm{mg} / 100 \mathrm{ml}$. Previous data on serum hemoglobin concentration in goat were not avilable in literature, but the mean value of serum hemoglobin in the present investigation was lied in the range given previously by different authors in bovine serum (SCHULTZLER and SIEGERT, 1963 and EL-SEBAIE, 1981).

A limited number of parameters will be reviewed in this section in order to examine their concentration in serum of healthy goats and the effect of different degree of hemolysis on the picture of such parameters. The obtained data of the examined constituents were generally in agreement with the published data by (GURTLER and 
IN-VITRO HAEMOLYSIS, GOATS SERUM

RICHTER, 1959; SOLBACH et al, 1962; BOYD et al, 1964; YOUNG et al, 1965). There were only relatively small differences between the mean values of the published data, this may could explained due to variations in breed, age, and methods used. On respect of the effect of hemolysis in variuos degree on the values of studied costituents, it can be concluded that the goats serum appears hemolysed, when the serum hemoglobin concentration exceeds a values of $132.06 \pm 0.427 \mathrm{mg} / 100$. The values fall within the range published previusly by GARAWAY, (1962); LAESSIG et al, (1976); DORNER et al, (1981) and EL-SEBAIE (1981). Slight degree of hemolysis exert its effect and causes adultration of values of serum constituents. The marked influence was shown in the concentration of serum hemoglobin which reach a value of $132.06 \mathrm{mg} / 100 \mathrm{ml}$. A less effects were showed on the values of serum aspartat aminotransferase which elevated from $23.6 \mathrm{U} / \mathrm{L}$ in non-hemolysed serum to reach $25.30 \mathrm{U} / \mathrm{L}$. Serum potassium first of all was markedly elevated when the serum appears slightly hemolysed. It could explained such rises in serum hemoglobin, aspartat amino transferase and serum potassium due to high concentration of such substances in red blood cells than in plasma.

Other costituents such as serum total bilirubin, serum total protein and serum chloride showed no significant elevation in their values. The abovementioned results are in agreement with the data given by CARAWAY, (1962); LAESSIG, et al, (1976); HENRY, et al, (1977); DORNER, et al, (1981) and EL-SEBAIE, (1981).

A prominant effect of hemolysis was observed when the serum was severly hemolysed, adultration not only include values of serum hemoglobin, aspartat amino transferase and potassium but also include some other parameters such as serum bilirubin. A sharp elevation in hemoglobin value was observed, the value reached $462.06 \mathrm{mg} / 100 \mathrm{ml}$, this value commonly obtained when the serum appears bloody. Similar elevation also observed on the determination of serum potassium and aspariat amino transferase (AST). Serum bilirubin value was less elevated when compared with other parameters. This results were agreed with (HENRY, et al, 1977); LAESSIG, et af, (1976) and EL-SEBAIE, (1981).

Finally it should be concluded that, a slight degree of serum hemolysis had a minimal effect in adultration of values of some serum constituenta such as aspartat amino transferase, and serum potassium, while the same degree of hemolysis had no effect on the other measured serum constituents.

Severaly hemolysed serum causes a significant elevation of values of aspartat amino transferase, serum potassium and serum total bilirubin, with exception of serum chloride. From this point of view the hemolysed serum samples from goats used in clinical chemistry assay, should be rejected.

\section{REFERENCES}

Behrendt, H. (1957): Chemistry of efythrosutes. Sprigfield III Charles \& Thoms publisher.

Boyd, J.W.; T.A. Douglas; C.M. Gould and Grimes, R.C. (1964): The interpretation of serum assay in cattle. Vet. Rec. 76, 567-574.

Caraway, W.T. (1962): Chemical and diagnostic specifity of laboratory tests. Am. J. Clin. Pathol. 37, $445-464$.

Dorher, J.L.; W.E. Hoffmann and T.F. Lock (1981): Effect of in vitro hemolysis on equine serum - chemical values. Am. J. Vet. Res. Vol. 42, 1519-1522.

El-Sebaie, H.A. (1981): Untersuchungen über den Hämoglobingehalt im Blutserum gesunder und kranker Rinder. Diss. Dr. Vet. Med. Giessen w. Germany.

Gürtler, H. and Richter, R. (1959): Zur Kenntnis der transaminasen im serum von Pferd, Rind and Schwein. Zbl. Vet. Med. 6, 705-713.

Henry, R.G.D.; D. Cannon and J.W. Winkelman (1977): Clinical chemistry. Med. Dept. Harper \& Row Publishers Hagerstown, Maryland. N.Y. Evanston, Sanfrancisco and London.

Laessig, H.R.A.A. Indriksons, D.J. Hassemer, T.A. Paskey and T.H. Schwartz (1976): Changes in serum chemical values as a result of prolonged contact with clot. Am. J. Clin. Pathol. 66, 598-604.

Martinek, R. (1966): Specimens for clinical laboratory analysis, collection and preservation Postgrad. Med. 37, 46-49.

McGann, C.H. and Carter (1960): The effect of hemolysis on the van den Bergh reaction for serum Bilirubin. J. Pediat. 57, 199-203. 
Richterich, R. (1978): Klinische chemie theorie und praxis. Akademische Verlaggesellschaft. Frankfurt / Main.

Schützler, G. and Siegert, M. (1963): Mikrobestimmungen von Hämoglobin in Hinblick auf die Frement-diagnostik im serum und plasma von Hunden und Pferden. Berl. Münch. tieräztl. Wschr. 77, 422-425.

Solbach, H.G.; A. Englelhardt, R. Marten (1962): Unterschiede der Enzymaktivitäten im serum und plasma und Ihre Bedeutung für die klinische Enzydiagnostik. Klini. Wsch. 40, 1136-1139.

Young, E.; R.L. Younger, D.L. Radeleff, H. Hunt, K. and B.S. Mclaran (1965): Some observations on certain serum enzymes of sheep. Am. J. Vet. Res. 26, 641-644.

Table (1): Normabvalues of some serum parameters in healthy goats

\begin{tabular}{ccccccr}
\hline $\begin{array}{c}\text { Serum } \\
\text { Parameters }\end{array}$ & $\begin{array}{c}\mathrm{Hb} \\
\mathrm{mg} / 100 \mathrm{ml}\end{array}$ & $\begin{array}{c}\text { Aspartat amino } \\
\text { transferase U/L }\end{array}$ & $\begin{array}{c}\text { Tatal } \\
\text { Bilirubin mol/L }\end{array}$ & $\begin{array}{c}\text { Total } \\
\text { Protein } \mathrm{g} / \mathrm{L}\end{array}$ & $\begin{array}{c}\text { Chloride } \\
\mathrm{mmol} / \mathrm{L}\end{array}$ & $\begin{array}{c}\text { Potassium } \\
\mathrm{mmol} / \mathrm{L}\end{array}$ \\
\hline Mean value & 120.73 & 23.6 & 11.35 & 99.08 & 109.6 & 5.26 \\
\hline S.E. & \pm 5.95 & \pm 3.16 & \pm 2.80 & \pm 1.11 & \pm 2.45 & \pm .93 \\
\hline
\end{tabular}

Table (2): Effect of slight degree of hemolysis on some serum parameters

\begin{tabular}{lcccccc}
\hline $\begin{array}{c}\text { Serum } \\
\text { Parameters }\end{array}$ & $\begin{array}{c}\mathrm{Hb} \\
\mathrm{mg} / 100\end{array}$ & $\begin{array}{c}\text { Aspoartat amino } \\
\text { Transferase U/L }\end{array}$ & $\begin{array}{c}\text { Total } \\
\text { Bilirubin mol/L }\end{array}$ & $\begin{array}{c}\text { Total } \\
\text { Protein } \mathrm{g} / \mathrm{L}\end{array}$ & $\begin{array}{c}\text { Chloride } \\
\mathrm{mmol} / \mathrm{L}\end{array}$ & $\begin{array}{c}\text { Potassium } \\
\mathrm{mmol} / \mathrm{L}\end{array}$ \\
\hline Mean value & 132.06 & 25.30 & 11.80 & 97.16 & 102.1 & \pm .84 \\
\hline S.E. & \pm 0.427 & \pm 1.07 & \pm 1.60 & \pm 1.23 & \pm 0.73 & \pm 0.30 \\
\hline & $n=10$ & & & & & \\
\hline
\end{tabular}

Table (3): Effect of severe degree of hemolysis on some parameters

\begin{tabular}{ccccccc}
\hline $\begin{array}{c}\text { Serum } \\
\text { Parameters }\end{array}$ & $\begin{array}{c}\mathrm{Hb} \\
\mathrm{mg} / 100\end{array}$ & $\begin{array}{c}\text { Aspartat amino } \\
\text { transferase U/L }\end{array}$ & $\begin{array}{c}\text { Total } \\
\text { Bilirubin } \mathrm{mol} / \mathrm{L}\end{array}$ & $\begin{array}{c}\text { Total } \\
\text { Protein } \mathrm{g} / \mathrm{L}\end{array}$ & $\begin{array}{c}\text { Chloride } \\
\mathrm{mmol} / \mathrm{L}\end{array}$ & $\begin{array}{c}\text { Potassium } \\
\mathrm{mmol} / \mathrm{L}\end{array}$ \\
\hline Mean value & 462.06 & 47.80 & 15.83 & 99.12 & 101.21 & 10.30 \\
\hline S.E. & \pm 0.10 & \pm 3.08 & \pm 2.82 & \pm 0.67 & \pm 6.87 & \pm 1.42 \\
\hline $\mathrm{n}=10$ & & & & & \\
\hline
\end{tabular}

